\title{
In Silico Comparison of Synthetic and Natural Molecules Bindings with Acetylcholinesterase Enzyme using Molecular Docking
}

\author{
Fouzia Mesli ${ }^{1}$, Salim Bouchentouf ${ }^{1,2,}{ }^{*}$, Amina Ghomri ${ }^{1,3}$, Noureddine Missoum ${ }^{1,4}$ and Said Ghalem ${ }^{1}$ \\ ${ }^{1}$ Laboratory of Naturals Products and Bioactives- LASNABIO, University of Tlemcen. B. P. 119, 13000 Tlemcen. \\ Algeria \\ ${ }^{2}$ Faculty of Technology, Doctor Tahar Moulay University of Saida, Algeria \\ ${ }^{3}$ High school of Applied Sciences ESSA Tlemcen. B. P. 165, 13000 Tlemcen. Algeria \\ ${ }^{4}$ Faculty of Scineces, Hassiba Benbouali University of Chlef, Algeria \\ Email: bouchentouf .salim@yahoo.fr
}

\begin{abstract}
Inhibition of Acetylcholinesterase (AChE) is an important approach for Alzheimer's disease $(\mathrm{AD})$ treatment. Different synthetic and natural inhibitors are used for Acetylcholinesterase inhibition. Synthetic inhibitors Polyphenols (Tacrine, Donepezil, Rivastigmine, Galantamine) and Natural molecules from Green tea which mainly contains catechins (Epicatechin, Epicatechin Gallate, Epigallocatechin, Epigallocatechin Gallate) are used to inhibit Acetylcholinesterase. In this work we use molecular docking methods to identify the ligand which has the best interaction energy with AChE among synthetic and natural products, and also descript binding affinity in purpose to design new inhibitor ligands. Obtained results from Docking and analyze of complexes parameters showed that the best affinity binding was observed for both (Galantamie and Epicatechin Gallete).This latter leads to same conclusion with experimentation inhibition study. We observed also that bulky group causes conformational rearrangement in the active pocket, which will probably give better interactions.
\end{abstract}

Keywords: Alzheimer; acetylcholinesterase enzyme; polyphenol; green tea; molecular docking.

\section{Introduction}

Alzheimer's disease (AD), also known as just Alzheimer's, is a chronic neurodegenerative disease that usually starts slowly and gets worse over time. It is the cause of $60 \%$ to $70 \%$ of cases of dementia. The most common early symptom is difficulty in remembering recent events (short-term memory loss). As a person's condition declines, they often withdraw from family and society. Gradually, bodily functions are lost, ultimately leading to death. Although the speed of progression can vary, the average life expectancy following diagnosis is three to nine years [1-2].

Several studies indicated that the Green tea is useful for the people suffering Alzheimer's disease (AD). The work of Katergaris et al. has proved that Green Tea Catechins GTC extracts or Epigallocatechin gallate EGCG in its pure form may serve as nootropic options in the prevention or treatment of neurodegeneration associated diseases such as $\mathrm{AD}$ [3]. The use of Acetylcholinesterase (AChE) inhibitors to treat symptoms caused by cholinergic imbalances in Alzheimer disease (AD) represented a rational approach[4].

Recently, Green Tea Catechins (GTC) have been related to a variety of different beneficial health effects particularly with respect to their potential for preventing and treating different cancers [5] cardiovascular diseases [6], and some of the neurodegenerative diseases [7] in humans. Accounting for at least half of the total GTC [8], the most predominant catechin found in green tea is Epigallocatechin gallate (EGCG), which has been ascribed numerous beneficial properties including antioxidant [9], antiinflammatory [10], anti-microbial [11] and anticancer effects [12]. With the development of theoretical methods in drug design it is nowadays possible to elucidate and compare between different inhibitors of the same enzyme, and get conclusions about the inhibition power of each inhibitor.

In this work our objective is to evaluate theoretically the AChE inhibition power of two series of 
inhibitors naturals (molecules of Green tea (GT) which mainly contains Catechins (Epicatechin, Epicatechin Gallate, Epigallocatechin, Epigallocatechin Gallate) and synthetics (tacrine, donepezil, rivastigmine, galantamine). By molecular docking we can study the complex (enzyme/inhibitor) formation and consequently delay its progression, in order to determine interaction of the complex (Natural and Synthetic) to the enzyme.

\section{$2 \quad$ Materials and Methods}

\subsection{Acetylcholinesterase Enzyme}

Acetylcholinesterase (HGNC symbol AChE), also known as AChE or acetylhydrolase, is the primary cholinesterase in the body. It is an enzyme that catalyzes the breakdown of acetylcholine and of some other choline esters that function as neurotransmitters. AChE is found at mainly neuromuscular junctions and in chemical synapses of the cholinergic type, where its activity serves to terminate synaptic transmission. It belongs to carboxylesterase family of enzymes. It is the primary target of inhibition by organo-phosphorus compounds such as nerve agents and pesticides. The structure and mechanism of action of AChE have been elucidated from the crystal structure of the enzyme [14].

\subsection{Synthetic Inhibitors of AChE}

An acetylcholinesterase inhibitor (often abbreviated AChEI) or anti-cholinesterase is a chemical or a drug that inhibits the acetylcholinesterase enzyme from breaking down acetylcholine, thereby increasing both the level and duration of action of the neurotransmitter acetylcholine. Acetylcholinesterase inhibitors are classified as reversible, irreversible, or quasi-irreversible (also called pseudo-irreversible) [15]. Acetylcholinesterase inhibitors (tacrine, donepezil, rivastigmine, galantamine), in the cholinergenic family, act to slow acetylcholinesterase activity in order to maintain high levels of acetylcholine, which is greatly reduced in patients with cholinergenic disease. 'Alzheimer's. Acetylcholine is a neurotransmitter of the brain involved in the transmission of messages to the centers of memory, reasoning and other processes of thought [16].

Donepezil is a specifically designed piperidine derivative with reversible acetylcholinesterase inhibitor activity. It has a much higher specificity for AChE inhibition compared with tacrine [17] and its CNS selectivity is highlighted by the lack of activity in peripheral tissue such as cardiac tissue or gut smooth muscle.

Rivastigmine is a brain selective carbamate AChe inhibitor. It is known as a 'pseudo-irreversible' inhibitor because it mimics ACh by binding with the enzyme AChe forming a carbamylated complex. This prevents further enzyme-catalysed hydrolysis of ACh for several hours after the drug has been eliminated from the plasma. Thus, despite a half- life of only $1 \mathrm{~h}$, rivastigmine has a duration of action of about $10 \mathrm{~h} \mathrm{[18].}$

Galantamine (Nivalin, Razadyne, Razadyne ER, Reminyl, Lycoremine) is used for the treatment of mild to moderate Alzheimer's disease and various other memory impairments, in particular those of vascular origin [19].

Tacrine, an aminoacridine, has several actions such as monoamine oxidase inhibition, potassium channel blockade and interaction with subtypes of muscarinic and nicotinic receptors. However the most prominent action is as a centrally active reversible cholinesterase inhibitor. Tacrine is rapidly absorbed and cleared by the liver during a first pass metabolism [20].

\subsection{Natural Inhibitors of AChE}

Tea is an aromatic beverage commonly prepared by pouring hot or boiling water over cured leaves of the camellia sinensis native to Asia. After water, it is the most widely consumed drink in the world. Tea is also a source of antioxidants in the form of polyphenols of different natures depending on the type and method of manufacture. Green tea contains mainly catechins (Epicatechin, Epicatechin Gallate, Epigallocatechin, Epigallocatechin Gallate), and its fermentation transforms them into theaflavins and thearubigines [21]. Gallocatechol or gallocatechin (GC) is a flavan-3-ol known as one of the antioxidants 
present in food. Epicatechin gallate (ECG) is a flavan-3-ol, one of the flavonoides, consequent in green tea. Epigallocatechin gallate (EGCG), is the most plentiful catechin in tea, is a polyphenol with a potential affection on the human health and disease. Indeed it is used in many dietary supplements.

Natural and synthetic inhibitors chosen for for studying inhibition of Acetylcholinesterase (AChE) are given in table1.

Table1: Synthetic and Natural for AChE

\begin{tabular}{|c|c|c|c|c|}
\hline Ligand & Name & IUPAC name & $\begin{array}{l}\text { PubChem } \\
\text { CID }\end{array}$ & $\begin{array}{l}\text { Molar mass } \\
(\mathrm{g} / \mathrm{mol})\end{array}$ \\
\hline 1 & $\begin{array}{l}\text { Donepezil } \\
\text { (Aricept) }\end{array}$ & $\begin{array}{l}\text { 2-[(1-benzylpiperidin-4-yl)methyl]-5,6- } \\
\text { dimethoxy-2,3-dihydroinden-1-one }\end{array}$ & 3152 & 379,492 \\
\hline 2 & $\begin{array}{l}\text { Rivastigmine } \\
\text { (Exelon) }\end{array}$ & $\begin{array}{l}{[3-[(1 \mathrm{~S})-1-(\text { dimethylamino)ethyl] phenyl }] \mathrm{N}-} \\
\text { ethyl-N-methylcarbamate }\end{array}$ & 77991 & 250,3367 \\
\hline 3 & $\begin{array}{l}\text { Galantamie } \\
\text { (Reminyl) }\end{array}$ & $\begin{array}{c}\text { (4aS,6R,8aS)-3-methoxy-11-methyl- } \\
\text { 4a,5,9,10,11,12-hexahydro-6H- } \\
\text { benzo[2,3] benzofuro[4,3-cd]azepin-6-ol }\end{array}$ & 9651 & 287,3535 \\
\hline 4 & Tacrine(Cognex) & 1,2,3,4-tetrahydroacridin-9-amine & 1935 & 198,2637 \\
\hline 5 & Epicatechin & $\begin{array}{c}\text { (2R,3R)-2-(3,4-dihydroxyphenyl)-3,4-dihydro- } \\
\text { 2H-chromene-3,5,7-triol }\end{array}$ & 72276 & 290.271 \\
\hline 6 & $\begin{array}{l}\text { Epicatechin } \\
\text { Gallate }\end{array}$ & $\begin{array}{c}\text { [(2R,3R)-2-(3,4-dihydroxyphenyl)-5,7- } \\
\text { dihydroxy-3,4-dihydro-2H-chromen-3-yl }] \\
\text { 3,4,5-trihydroxybenzoate }\end{array}$ & 107905 & 442.37 \\
\hline 7 & Epigallocatechine & $\begin{array}{l}\text { (2R,3S)-2-(3,4,5-trihydroxyphenyl)-3,4- } \\
\text { dihydro-2H-chromene-3,5,7-triol }\end{array}$ & 65084 & 306.27 \\
\hline 8 & $\begin{array}{l}\text { Epigallocatechine } \\
\text { Gallate }\end{array}$ & $\begin{array}{l}{[(2 \mathrm{R}, 3 \mathrm{R})-5,7 \text {-dihydroxy-2-(3,4,5- }} \\
\text { trihydroxyphenyl)-3,4-dihydro-2H-chromen-3- } \\
\text { yl] 3,4,5-trihydroxybenzoate }\end{array}$ & 65064 & 458.372 \\
\hline
\end{tabular}

\subsection{Preparation and Optimization of both Enzyme and Inhibitors Natural and Synthetic}

Download of Acetylcholinesterase was done from PROTEIN DATA BANK (code 4TVK) with threedimensional structure obtained by X-ray diffraction (resolution $2.3 \AA$ ) (Figure 1). Note that the Acetylcholinesterase crystallizes as a monomer (Figure 1) with 534 residues and 8377 atoms. Compounds of inhibitors were downloading from Pub Chem data base. Using MOE software (Molecular operating environment) [22]. The active site in the enzyme and we minimize the energy of both enzyme and molecules $(\mathrm{a}, \mathrm{b}, \mathrm{c})$. Energy minimizing was done under following conditions: Temperature $=300^{\circ} \mathrm{K}$, $\mathrm{pH}=7$, the geometry was performed using the field strengths in the MMFF94x implanted in MOE and Hamiltonian AM1. Docking was performed using London dG force and refinement of the results was done using Force field energy. Figure 2 shows the active site of the enzyme with molecule of cocrystallization. Minimized energy of ligands and their toxicity are obtained by MOE software (table 4).

Table 2. Synthetic polyphenols inhibitors of AChE

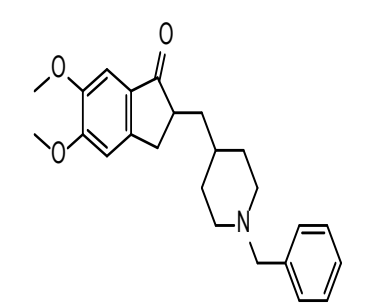

Ligand1 (CID 3152)<smiles>CCN(C)C(=O)Oc1cccc([C@H](C)N(C)C)c1</smiles>

Ligand2 (CID 77991)<smiles>COc1ccc2c3c1O[C@]1(C)C[C@H](O)CC[C@]3(CCN(C)C2)C1</smiles>

Ligand3 (CID 9651)<smiles>Nc1c2c(nc3ccccc13)CCCC2</smiles>

Ligand 4(CID 1935) 
Table 3. Natural inhibitors of AChE<smiles>Oc1cc(O)c2c(c1)O[C@H](c1ccc(O)c(O)c1)[C@H](O)C2</smiles><smiles>O=C(O)C1Cc2c(O)cc(O)cc2O[C@H]1c1ccc(O)c(O)c1</smiles>

Ligand6 (CID107905)<smiles>Oc1cc(O)c2c(c1)O[C@H](c1cc(O)c(O)c(O)c1)[C@H](O)C2</smiles>

Ligand7 (CID65084)<smiles>O=C(O)C1Cc2c(O)cc(O)cc2O[C@H]1c1cc(O)c(O)c(O)c1</smiles>

Ligand8 (CID 65064)

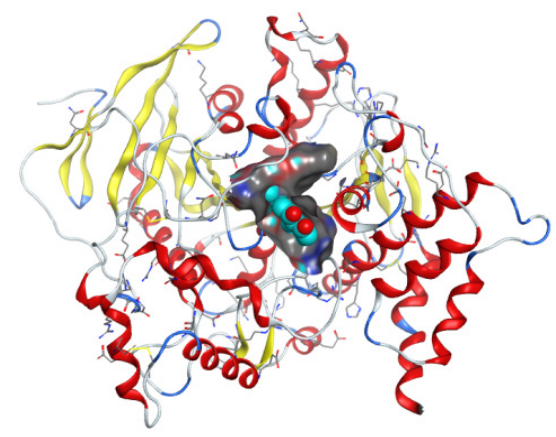

Figure 1: 3D structure of (AChE)

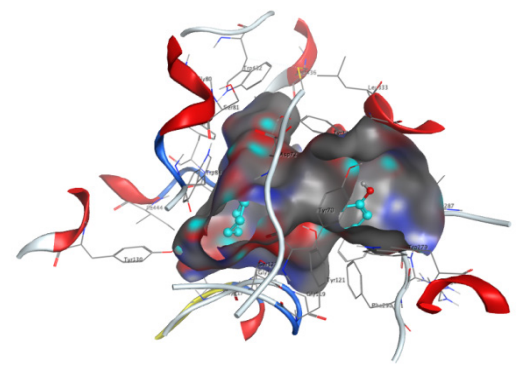

Figure 2: Isolated enzyme active site.

Table 4. Energy minimization results of synthetic and natural ligands

\begin{tabular}{cccccc}
\hline Ligand & Molecules & Energies $(\mathbf{K c a l} / \mathbf{m o l})$ & LogP & LogS & Toxcicity \\
\hline 1 & Donepezil & $8.70672 \mathrm{e}+001$ & 3.21 & -4.20 & No \\
2 & Rivastigmine & $3.17161 \mathrm{e}+001$ & 1.44 & -1.07 & No \\
3 & Galantamie & $6.76170 \mathrm{e}+001$ & 0.70 & -2.27 & No \\
4 & Tacrine & $4.82338 \mathrm{e}+001$ & 2.70 & -2.78 & No \\
5 & Epicatechin & $5.77003 \mathrm{e}+001$ & 1.64 & -1.74 & No \\
6 & Epicatechin gallate & $7.73960 \mathrm{e}+001$ & 2.62 & -3.03 & No \\
7 & Epigallocatechine & $5.56122 \mathrm{e}+001$ & 1.35 & -1.37 & No \\
8 & Epigallocatechine Gallate & $7.64465 \mathrm{e}+001$ & 2.33 & -2.67 & No \\
\hline
\end{tabular}

\subsection{Docking and Building Complexes}

The next step consists of positioning of ligands in AChE active site. For this, we used the Molecular 
Docking Module using MOE software. Once the ligand -receptor complex is formed, the most stable conformation is adapted and will show the lowest energy. The purpose of the Dock application is looking at favorable conformational binding between medium size ligands and a not so soft macromolecular target, which is usually a protein [24]. For each compound a number of conformations called poses were generated for the first approach to identify favorable binding modes [25]. The search for binding modes is generally constrained to a small specific region of the receptor called the active site.

\section{$3 \quad$ Results and Discussion}

Table 5. Energy Balance of complexes formed between ligands and $\mathrm{AChE}(\mathrm{Kcal} / \mathrm{mol})$.

\begin{tabular}{cccccccc}
\hline Complex & Score & Rmsd-refine & E-Conf & E-PLACE & E-SCORE1 & E-REFINE & E-SCORE2 \\
\hline Ligand ref & -18.208 & 2.0142 & 137.1829 & -72.5964 & -13.2105 & 19.2969 & -18.2089 \\
Complexe-1 & -14.080 & 1.72080147 & 28.4046 & -71.1366 & -12.4092 & 0.7917 & -14.0808 \\
Complexe-2 & -12.199 & 1.3913 & -59.1072 & -46.4278 & -11.3380 & -11.80745 & -12.1994 \\
Complexe-3 & -15.890 & 1.0627 & 4.5286 & -56.8647 & -12.7848 & 34.1320 & -15.8909 \\
Complexe-4 & -9.4663 & 0.9120 & 38.2057 & -62.1670 & -9.9031 & -12.7840 & -9.4663 \\
Complexe-5 & -16.1771 & 0.7566 & 25.6229 & -89.2038 & -15.3782 & 3.0038 & -16.1771 \\
Complexe-6 & -21.1324 & 2.3473 & 45.5496 & -94.0829 & -16.7406 & -1.7876 & -21.1324 \\
Complexe-7 & -16.5014 & 1.7588 & 27.0696 & -120.7888 & -14.7346 & -6.9466 & -16.5014 \\
Complexe-8 & -19.2184 & 1.2014 & 23.7697 & -142.832 & -17.0954 & -26.1940 & -19.2184 \\
\hline
\end{tabular}

$S$ : the final score; is the score of the last step, rmsd_refine: the mean square deviation between the $l$ aying before refinement and after refinement pose, E_conf: energy conformer, E_place: score of the placement phase, E_scor1: score the first step of notation, E_refine: score refinement step and number of conformations generated by ligand E_scor2: score the first step notation, number of poses: Number of conformations [22].

Table 6. Interactions patterns observed in the determined complexes between the ligands and the corresponding amino acid in AChE.

\begin{tabular}{|c|c|c|c|c|c|c|c|c|c|}
\hline \multirow{4}{*}{$\begin{array}{l}\text { Ligand } \\
1\end{array}$} & \multirow{4}{*}{$\begin{array}{l}\text { Name } \\
\text { Donepezil }\end{array}$} & \multicolumn{2}{|c|}{ Ligand } & \multicolumn{2}{|c|}{ Receptor } & \multirow{2}{*}{\multicolumn{2}{|c|}{$\frac{\text { Interaction }}{\text { (A)H-donor }}$}} & \multirow{3}{*}{$\begin{array}{l}\text { Distance } \\
2.97 \\
244\end{array}$} & \multirow{2}{*}{$\frac{\mathrm{E}(\mathrm{kcal} / \mathrm{mol})}{-2.3}$} \\
\hline & & O6 & 6 & $\mathrm{O}$ & TYR 70 & & & & \\
\hline & & O8 & 8 & OE1 & GLN $\quad 69$ & $(\mathrm{~A})$ & H-donor & & 1.2 \\
\hline & & O11 & 11 & OG & SER 200 & $(\mathrm{~A})$ & H-donor & 2.57 & -1.4 \\
\hline \multirow{4}{*}{2} & \multirow{4}{*}{ Rivastigmine } & $\mathrm{O} 2$ & 2 & $\mathrm{OH}$ & TYR 121 & $(\mathrm{~A})$ & H-acceptor & 2.77 & -3.4 \\
\hline & & N3 & 3 & OE1 & GLU 199 & $(\mathrm{~A})$ & ionic & 3.52 & -3.1 \\
\hline & & N3 & 3 & OE2 & GLU 199 & $(\mathrm{~A})$ & ionic & 3.95 & -1.5 \\
\hline & & $\mathrm{C} 10$ & 11 & 6-ring & PHE 330 & $(\mathrm{~A})$ & H-pi & 4.76 & -0.6 \\
\hline \multirow{3}{*}{3} & \multirow{3}{*}{ Galantamie } & $\mathrm{N} 4$ & 4 & OE1 & GLU 199 & $(\mathrm{~A})$ & H-donor & 2.63 & -15.8 \\
\hline & & N4 & 4 & OE1 & GLU 199 & $(\mathrm{~A})$ & ionic & 2.63 & -7.5 \\
\hline & & N4 & 4 & OE2 & GLU 199 & $(\mathrm{~A})$ & ionic & 3.54 & -1.7 \\
\hline 4 & Tacrine & $\begin{array}{l}\text { No } \\
\text { intera }\end{array}$ & action & & & & & & \\
\hline 5 & Epicatechin & O3 & 4 & OE1 & GLU 199 & $(\mathrm{~A})$ & H-donor & 2.77 & -4.7 \\
\hline \multirow{3}{*}{6} & \multirow{3}{*}{$\begin{array}{l}\text { Epicatechin } \\
\text { gallate }\end{array}$} & $\mathrm{O} 4$ & 4 & OE1 & GLU 199 & $(\mathrm{~A})$ & H-donor & 2.70 & -4.3 \\
\hline & & $\mathrm{O} 8$ & 8 & $\mathrm{O}$ & SER 81 & $(\mathrm{~A})$ & pi-pi & 3.05 & -1.6 \\
\hline & & 6-ring & & 6-ring & PHE 330 & (A) & H-donor & 3.58 & -0.0 \\
\hline \multirow{2}{*}{7} & \multirow{2}{*}{$\begin{array}{l}\text { Epigallocatec } \\
\text { hine }\end{array}$} & $\mathrm{O} 7$ & 8 & $\mathrm{O}$ & TYR 70 & $(\mathrm{~A})$ & H-donor & 3.00 & -2.1 \\
\hline & & 6-ring & & $\mathrm{OH}$ & TYR 121 & $(\mathrm{~A})$ & pi-H & 4.51 & -0.6 \\
\hline \multirow{3}{*}{8} & \multirow{3}{*}{$\begin{array}{l}\text { Epigallocatec } \\
\text { hine Gallate }\end{array}$} & O6 & 6 & $\mathrm{O}$ & TYR 70 & (A) & I-donor & 2.97 & -2.3 \\
\hline & & $\mathrm{O} 8$ & 8 & OE1 & GLN $\quad 69$ & $(\mathrm{~A})$ & H-donor & 2.44 & 1.2 \\
\hline & & O11 & 11 & OG & SER 200 & $(\mathrm{~A})$ & H-donor & 2.57 & -1.5 \\
\hline
\end{tabular}


Results presented in tables 5 and 6 show that the orientation of the ligands plays a significant role for the positioning of the ligands in the active site of the enzyme, one can conclude that the introduction of bulky groups causes a rearrangement of conformation inside the cavity of the active site, which will be probably the complementarity and consequently the activity [26]. 2D molecular method of the screen has been attributed to the MOE (Molecular Operating Environment) software, which is designed to visualize the active sites of the complex (protein-ligand). The ligand is prepared and made with an improved 2D depiction layout algorithm, and protein residues version are arranged around it to indicate links spatial proximity. Residues are marked with their amino acid code of 3 letters, and job classification [27-28]. If there are multiple channels in the system, the positions are prefixed by the letters of the alphabet. Interactions between $2.5 \AA$ and $3.1 \AA$ are considered high and those between $3.1 \AA$ and $3.55 \AA$ are average. Greater than $3.55 \AA$ interactions are weak [29].

Table 6 also shows that for the tow best inhibitors interaction with active site is assured by interaction with the GLU 199 amino acid.

\subsection{Synthetic Compounds}

These results show that the complex- 3 has the lowest energy $(-15.8909054 \mathrm{Kcal} / \mathrm{mol})$ and is more active than complex - $1(-14.0808125 \mathrm{Kcal} / \mathrm{mol})$ which is more active than complex -2 (Figure 3c) $(-12.1994009$ $\mathrm{Kcal} / \mathrm{mole})$.

For complex 3 (Figure 3a): Galantamie interacts with the amino acid [GLU 199 (A) H-donor; GLU 199 (A) ionic (OE1, OE2)] at a distance of $2.63 ; 2.63 ; 3.54 \AA$, respectively (for the $1^{\text {st }}$ and $2^{\text {nd }}$ strong interaction, $3^{\text {rd }}$ average interaction), with the existence of two electric forces PHE 330 and TRP 84 which suggest that Galantamie has important binding affinity with Acetylcholinesterase and interferes with [GLU 199 (A) H-donor; GLU 199 (A) ionic (OE1, OE2)] [30].
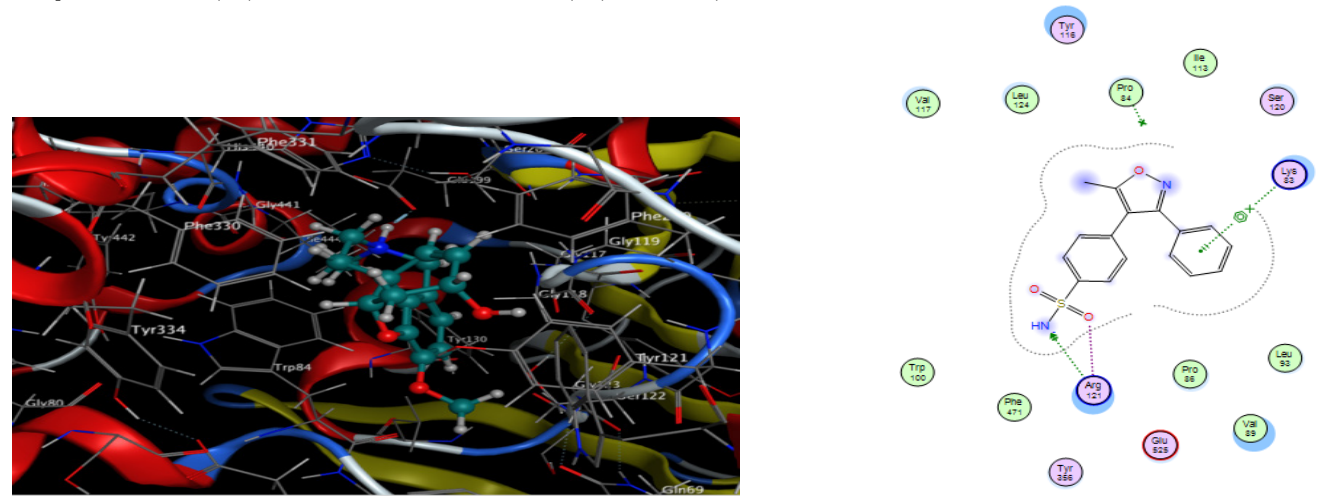

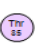

;:

Figure 3 (a). Diagram interaction of complex-3 (AChE+Galantamie)
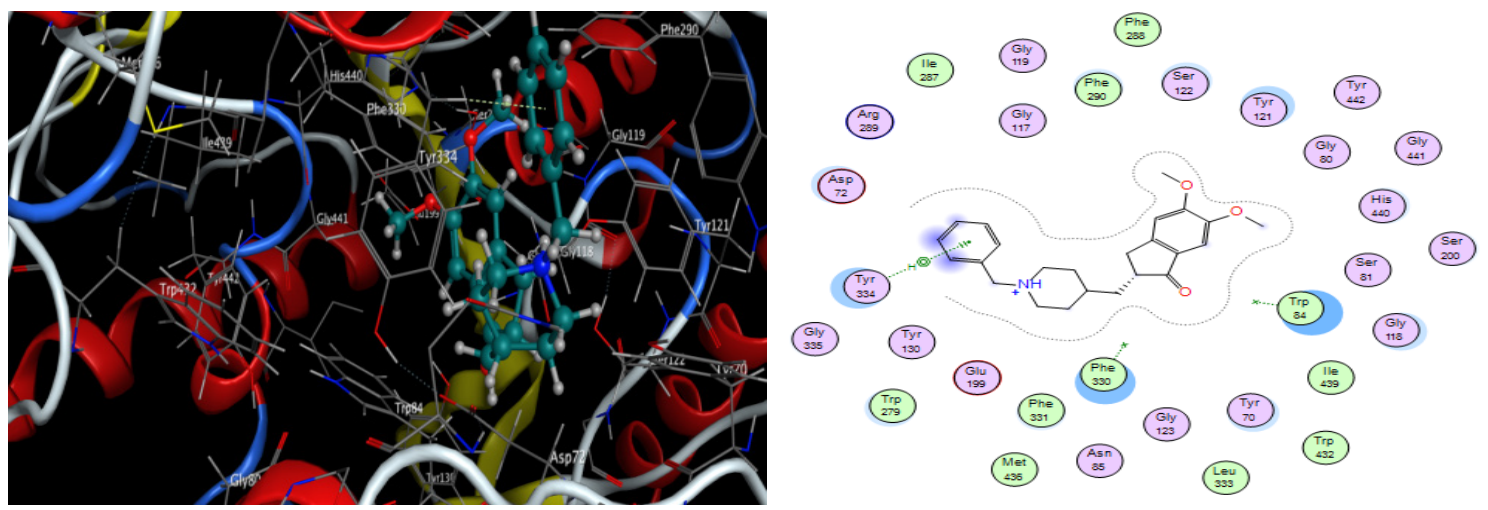

Figure 3 (b). Diagram interaction of complex-1(AChE+Donepezil)

For complex 1 (Figure 3b): Donepezil interacts with the amino acid [TYR 334 (A) pi-H] at a distance of $4.03 \AA$ (for the 1st weak interaction), with the existence of two electric forces PHE 330; TRP 84 
which suggest that Donepezil can have good affinity interaction with Acetylcholinesterase and interfere with [TYR 334 (A) pi-H] [30].

For complex 2 (Figure 3c): Rivastigmine interacts with the amino acid [TYR 121 (A) H-acceptor; GLU 199 (A) ionic (OE1, OE2)]; PHE 330 (A) H-pi] at a distance of 2.77; 3.52.
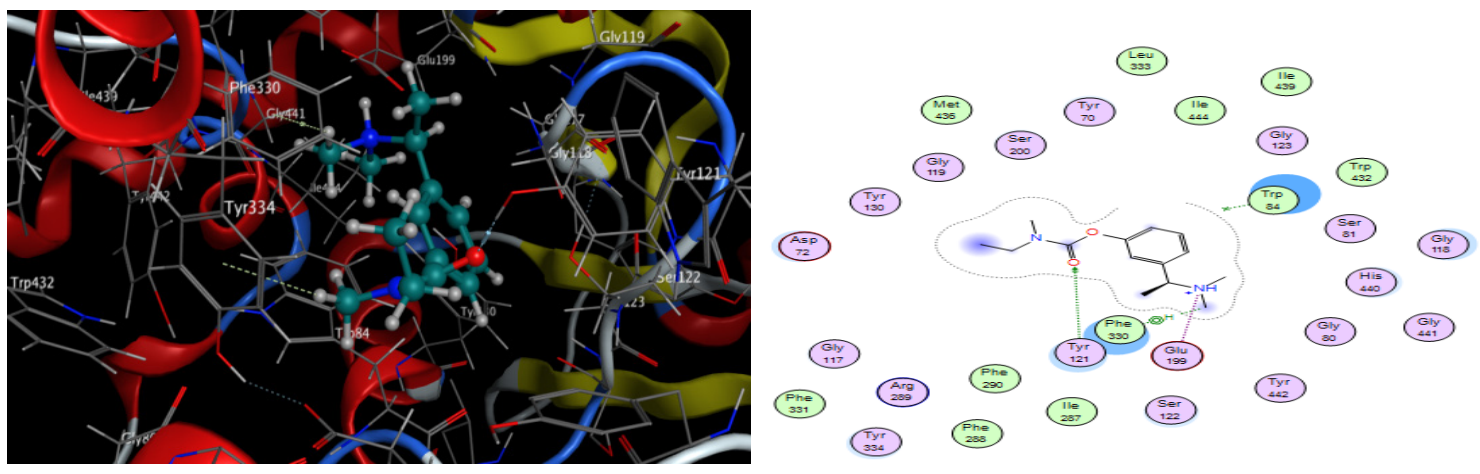

Figure 3 (c). Diagram interaction of complex-2 (AChE+Rivastigmine)

\subsection{Natural Compounds}

These results show that the complex-6 has the lowest energy $(-21.1324406 \mathrm{Kcal} / \mathrm{mol})$ and is more active than complex $-8(-19.218462 \mathrm{Kcal} / \mathrm{mol})$ which is more active than complex $-3(-16.5014267 \mathrm{Kcal} / \mathrm{mole})$.

The energy of the reference ligand is important in comparison with that obtained by the Natural ligands Epicatechin gallate and Epigallocatechine Gallate. Therefore, we can validate Epicatechin Gallate as a reference inhibitor (Figure 4a).

Energy complex (Ref: -18.2089138Kcal/mol, Epigallocatechine Gallate $-19.218462 \mathrm{Kcal} / \mathrm{mol}$ and Epicatechin Gallate -21.1324406 Kcal/mol).

For complex 6 (Figure 4b): Epicatechin gallate interacts with the amino acid [GLU 199 (A) H-donor $(\mathrm{OE} 1 ; \mathrm{O})$; PHE $330(\mathrm{~A})$ pi-pi] at a distance of $2.70 ; 3.05 ; 3.58 \AA$, respectively (for the $1^{\text {st }}$ and $2^{\text {nd }}$ strong interaction, $3^{\text {rd }}$ weak interaction), with the existence of one electric force TRP 84 which suggests that Epicatechin gallate can inhibit Acetylcholinesterase and interfere with [GLU 199 (A) H-donor (OE1; O) ; PHE 330 (A\& [30].

For complex 8 (Figure 4c): Epigallocatechine Gallate interacts with the amino acid [TYR 70 (A) Hdonor; GLN 69 (A) H-donor; SER 200 (A) H-donor] at a distance of 2.97: 2.44; $2.57 \AA$, respectively ( for the $1 \mathrm{st}, 2^{\text {nd }}$ and $3 \mathrm{rd}$ strong interaction), with the existence of two electric forces PHE 330; TRP 84 which suggest that Epigallocatechine Gallate can inhibit Acetylcholinesterase and interfere with [TYR 70 (A) H-donor; GLN 69 (A) H-donor; SER 200 (A) H-donor] [30].

For complex 7 (Figure 4d): Epigallocatechine interacts with the amino acid [TYR 70 (A) H-donor; TYR 121 (A) pi-H] at a distance of $3.00 ; 4.51 \AA$, respectively ( for the $1^{\text {st }}$ strong interaction; and $2^{\text {nd }}$ weak interaction) with the exixtence of two electric forces PHE 330; TRP 84 which suggest that Epigallocatechine can inhibit Acetylcholinesterase and interfere with [TYR 70 (A) H-donor; TYR 121 (A) pi-H ] [30].

The inhibitor of the co-cristalisation 2-(2-[(6-chloro-1, 2, 3, 4-tetrahydroacridin-9-yl) amino]-5hydroxynaphthalene-1; 4-dione Chain $\mathrm{A}_{25} \mathrm{H}_{22} \mathrm{ClN}_{3} \mathrm{O}_{3}$ (TJH).

Energy (Galantamie - $15.8909054 \mathrm{Kcal} / \mathrm{mol}<$ Donepezil $-14.0808125 \mathrm{Kcal} / \mathrm{mol}<$ Rivastigmine 12.1994009 Kcal/mol).

Energy (Epicatechin Gallate $\quad-21.1324406 \mathrm{Kcal} / \mathrm{mol}<$ Epigallocatechine Gallate $19.218462 \mathrm{Kcal} / \mathrm{mol}<$ Epigallocatechine $-16.5014267 \mathrm{Kcal} / \mathrm{mol}$ ).

Galantamie and Epicatechin Gallate would be the best to slow down the evolution of studied pathology (Alzheimer's disease (AD).

The examination of the enzymatic cavity confirms that the structure of natural inhibitor Epicatechin gallate with the groupings of atoms (O4, O8) presents a strong interaction hydrogen bond with [GLU 199 (A) H-donor (OE1; O)] and the structure of inhibitor synthetic Galantamie with the atom (N4) presents a strong interaction hydrogen bond with [GLU 199 (A) H-donor; GLU 199 (A) ionic (OE1)] and one better complementarity with Acetylcholinesterase (AChE). 


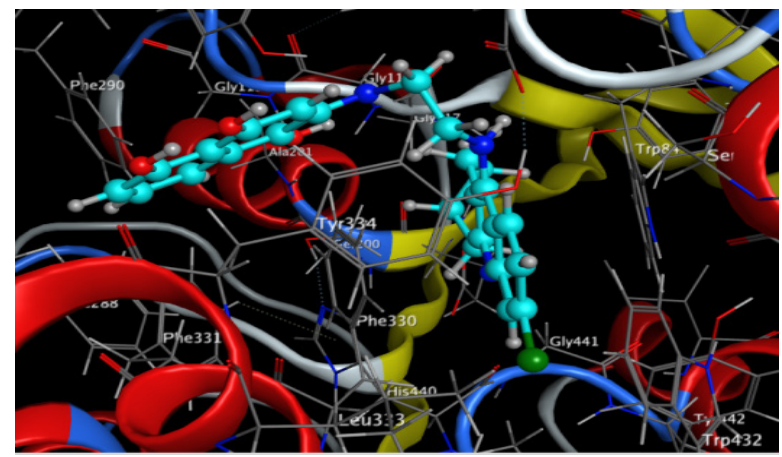

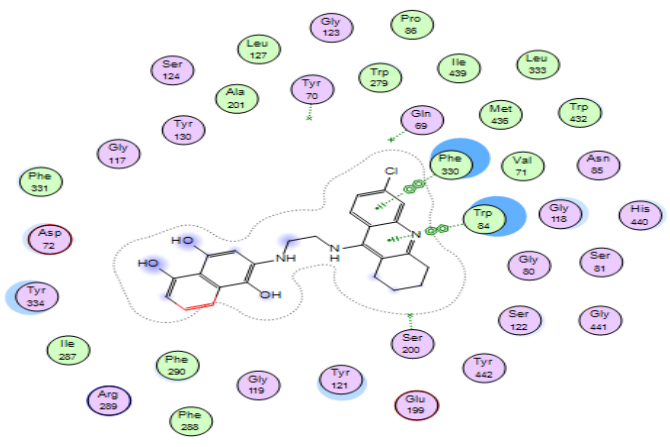

Figure 4 (a). Diagram interaction of complex-Lig Ref (AChE + TJH)

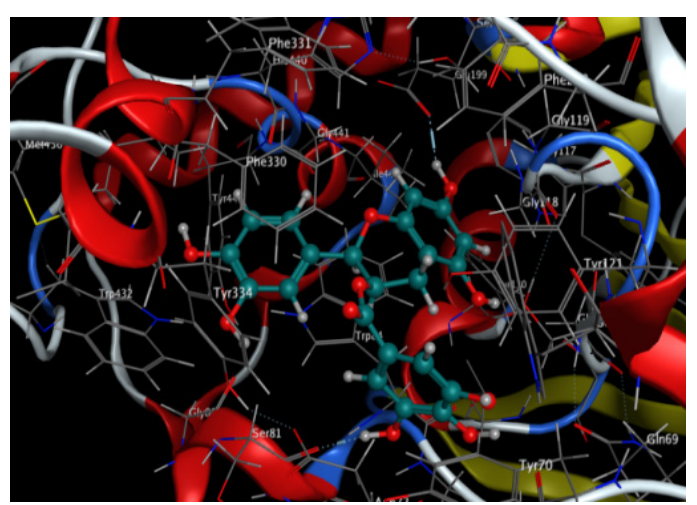

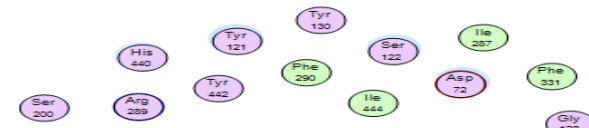

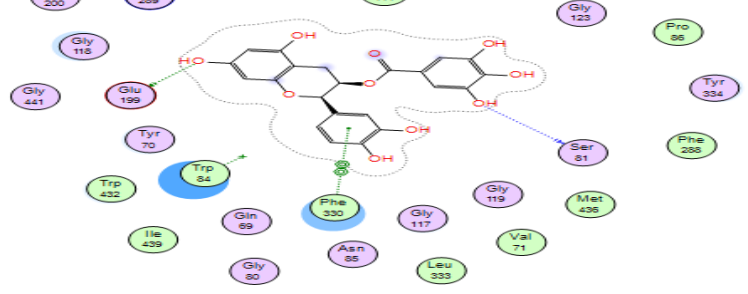

Figure 4 (b). Diagram interaction of complex-2 (AChE + Epicatechin Gallate)
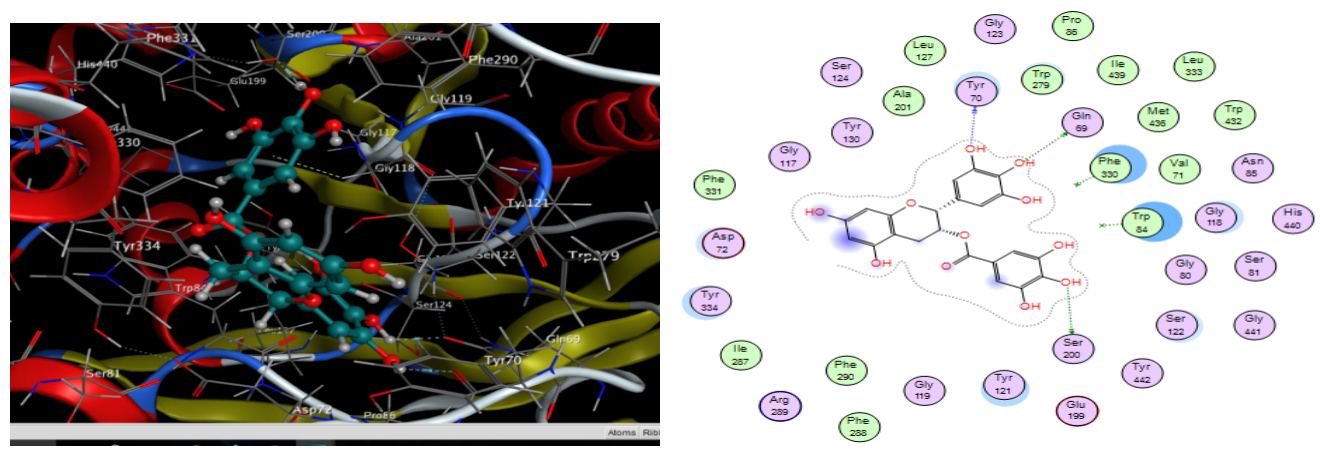

Figure 4 (c). Diagram interaction of complex-4 (AChE + Epigallocatechine Gallate)
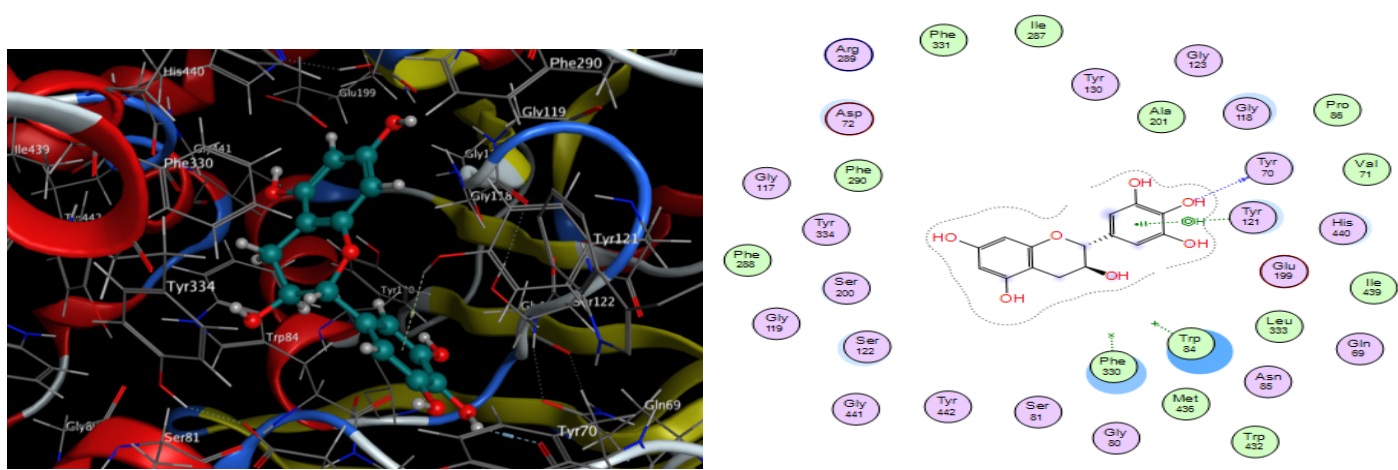

Figure 4 (d). Diagram interaction of complex-3 (AChE + Epigallocatechine) 


\section{Conclusion}

Acetylcholinesterase (AChE) inhibition analyses by studying interactions and binding with different synthetic and natural ligands has been investigated. Study result showed Polyphenol (Galantamieligand 3 ) has the best binding with enzyme and may present the best inhibition activity of AChE, whereas, from green tea Epicatechin Gallate has the best interaction with $\mathrm{AChE}$ which may be the best natural inhibitor. Natural compounds are in accordance with Lipinski rules for drug orally administration [31-32]. On the other hand one comparing between those two inhibitors we conclude that the natural inhibitor present better activity compared to synthetic one and it can contribute as an efficient treatment of the Alzheimer disease. Because of none signaled side effect of Epicatechin Gallate on human health, this latter has to be more investigated to perform his activity and power inhibition using bulky group. Also these results are very significant in field of phototherapy and Alzheimer diseases prevention.

\section{Conflict of Interest}

The authors declare no conflict of interest.

\section{Authors' Declaration}

The authors hereby declare that the work presented in this article is original and that any liability for claims relating to the content of this article will be borne by them.

Acknowledgements

Authors are thankful to LASNABIO laboratory for providing support for this work.

\section{References}

1. Querfurth HW, LaFerla FM (2010) Alzheimer's disease. The New England Journal of Medicine 28 January 362 (4): $329-44$.

2. Todd S, Barr S, Roberts M, Passmore, AP (2013) Survival in dementia and predictors of mortality: a review. International Journal of Geriatric Psychiatry November 28 (11): 1109-24.

3. Katergaris N, Dufficy L, Roach PD, Naumovski N (2015) Green tea catechins as neuroprotective agents: systematic review of the literature in animalpre-clinical trials. Adv Food Technol Nutr Sci Open J 1(2): 48-57.

4. Lane, Roger M, Miia Kivipelto, and Nigel H (2004) Greig. Acetylcholinesterase and its inhibition in Alzheimer disease. Clinical neuropharmacology 27(3): 141-149.

5. Khan MA, Hussain, A, Sundaram MK, et al. (2015) (-)-Epigallocatechin-3-gallate reverses the expression of various tumor-suppressor genes by inhibiting DNA methyltransferases and histone deacetylases in human cervical cancer cells. Oncol Rep 33(4): 1976-1984.

6. Nabavi SM, Daglia M, Moghaddam AH, Nabavi SF, Curti V (2014) Tea consumption and risk of ischemic stroke: a brief review of the literature. Curr Pharm Biotechnol 15(4): 298-303.

7. Matsushita K (2014) Epigallocatechin gallate suppresses LPS endocytosis and nitric oxide production by reducing Rab5-caveolin-1 interaction.Biomed Res. 35(2): 145-151.

8. Cai J, Jing D, Shi M, et al. (2014) Epigallocatechin gallate (EGCG) attenuates infrasound-induced neuronal impairment by inhibiting microglia-mediated inflammation J Nutr Biochem 25(7): 716-725.

9. Vuong QV, Golding JB, Nguyen M, Roach PD (2010) Extraction and isolation of catechins from tea. J Sep Sci 33(21): 3415-3428.

10. Lee HS, Jun JH, Jung EH, Koo BA, Kim YS (2014)Epigalloccatechin-3-gallate inhibits ocular neovascularization and vascular permeability in human retinal pigment epithelial and human retinal microvascular endothelial cells via suppression of MMP-9 and VEGF activation. Molecules 19(8):12150-12172.

11. Betts JW, Wareham DW (2014) In vitro activity of curcumin in combination with epigallocatechin gallate (EGCG) versus multidrug-resistant Acinetobacter baumannii. BMC Microbiol 14, 172

12. Reygaert WC (2014) The antimicrobial possibilities of green tea. Front Microbiol 5, 434.

13. Saiko P, Steinmann MT, Schuster H, et al. (2015) Epigallocatechin gallate, ellagic acid, and rosmarinic acid perturb dNTP pools and inhibit de novo DNA synthesis and proliferation of human HL-60 promyelocytic leukemia cells: Synergism with arabinofuranosylcytosine. Phytomedicine 22 (1): 213-222. 
14. Sussman JL, Harel M, Silman I. (1993) Three-dimensional structure of acetylcholinesterase and of its complexes with anticholinesterase drugs. Chem. Biol. Interact. June 87 (1-3): 187-97.

15. Colovic MB, Krstic, Danijela Z, Lazarevic-Pasti, Tamara D, Bondzic, Aleksandra M, Vasic, Vesna M (2013) Acetylcholinesterase Inhibitors: Pharmacology and Toxicology. Current Neuropharmacology 11 (3): 315-335.

16. Bezerra da Silva, Cristiane, et al. (2016) Effect of donepezil, tacrine, galantamine and rivastigmine on acetylcholinesterase inhibition in Dugesia tigrina. Molecules 21.1: 53.

17. Sugimoto H, Iimura Y, Yamanishi Y, Yamatsu K (1992) Synthesis and anti-acetylcholinesterase activity of 1benzyl-4-[5, 6-dimethoxy-1-indanon-2-yl] methylpiperidine hydrochloride (E2020) and related compounds. Bioorg Med Chem Lett 2: 871-876

18. Anand R, Gharabawi G, Enz A (1996) Efficacy and safety results of the early phase studies with Exelon (ENA 713) in Alzheimer's disease: an overview. J Drug Dev Clin Pract 8: 109-116.

19. Heinrich M, Teoh HL (1992) Galanthamine from snowdrop - the development of a modern drug against Alzheimer's disease from local Caucasian knowledge. Journal of Ethnopharmacology (2-3): 147-162.

20. Selen A, Balogh L, Siedlik P (1988) Pharmacokinetics of tacrine in healthy subjects. Pharm Res. 5: 218.

21. Raja S (2017) INVESTIGATION OF HEPATOPROTECTIVE AND ANTIOXIDANT ACTIVITIES OF INDIAN MEDICINAL PLANTS.

22. Molecular Operating Environment (MOE), Chemical Computing Group, Montreal, Quebec, Canada10, 2013.

23. Powers JP, Piper DE, Li Y, Mayorga V, Anzola J, Chen JM, et al. (2006) SAR and mode of action of novel non-nucleoside inhibitors of hepatitis C NS5b RNA polymerase. J Med Chem 49(3).

24. Goto J, Kataoka R, Muta H, and al. (2008) ASEDock-docking based on alpha spheres and excluded volumes J Chem Inf Model 48, 583-590.

25. Manikrao AM, Mahajan1 NS, Jawarkar RD, Mahajan DT, Masand2 VH, TBen Hadda (2011) Docking Studies of few C-3 Substituted Azapteridines as Hepatitis C Virus RNA-Dependent RNA Polymerase inhibitors Scholars Research Library. J. Comput. Method. Mol. Design 35-45.

26. Labute P, Williams C, Feher M, Sourial E, Schmidt JM. (2001) Flexible alignment of small molecules J. Med. Chem. 44:1483-1490.

27. (a) Clark AM, Labute P, Santavy M (2006) Journal of chemical information and modeling . J. Chem.46, Inf. Model. 1107-1123.

28. Clark AM, Labute P (2008) Clark, A. M., \& Labute, P. (2008). Detection and assignment of common scaffolds in project databases of lead molecules J. Med. Chem. 52: 469-483

29. Ritchie D, Macromolecular Docking Using Spherical Polar Fourier Correlations, Department of Computing Science, University of Aberdeen, copyright @ $1996-2005$

30. Yamaguchi H, Kamiie K, Kidachi Y, Noshita T, Umetsu H, Fuke, Y, Ryoyama K (2014). Intracellular accumulation of structurally varied isothiocyanates correlates with inhibition of nitric oxide production in proinflammatory stimuli-activated tumorigenic macrophage-like cells. Bioorganic \& medicinal chemistry 22(1): 440-446.

31. Lipinski CA. (2004). Lead- and drug-like compounds: The rule-of-five revolution. Drug Discovery Today: Technologies.1 (4):337-342.

32. Lipinski CA, Lombardo F, Dominy BW, Feeney PJ. (1997). Experimental and computational approaches to estimate solubility and permeability in drug discovery and development settings. Adv. Drug Deliv. Rev.23:3-25. 